\section{User satisfaction with public and private dental services for different age groups in Brazil}

\author{
Satisfação de usuários com serviços \\ odontológicos públicos e privados entre \\ diferentes grupos etários no Brasil
}

\section{Satisfacción de usuarios de servicios dentales públicos y privados para diferentes grupos de edad en Brasil}

\begin{abstract}
This article aimed to describe the levels of user satisfaction in different age groups and to study the association between user satisfaction and different types of dental services in a representative sample of Brazilians. This study is based on the Brazilian Oral Health Survey, which evaluated the dental health of adolescents, adults and older adults in 177 Brazilian cities. The outcome variable was user satisfaction, related to the last dental visit, evaluated in a five-level Likert-type scale. The main exposure variable was the type of dental service (public service, private service, health plan or insurance). The independent variables were DMFT (decay, missing and filled teeth); pain intensity in the past six months; reason for the last dental visit; perceived need for treatment; frequency of use of dental services; sex; equivalent income; and educational level. An ordered logistic regression analysis was performed separately for each age group. Few participants evaluated the services as bad or very bad (4.3\% of adolescents, $6.1 \%$ of adults and $4.1 \%$ of older adults). In the crude model, the use of public services was associated with lower satisfaction than the use of private services and health plans between all groups. However, after adjusting by covariates, this association remained only in adolescents, who showed lower satisfaction with the public service compared to the private service and health plans. In general, Brazilians are satisfied with dental services, but, among adolescents, the use of public services was associated with lower satisfaction. Public services may be focused on issues related to children, adults and older adults, and not to the adolescent audience, which has specific demands.
\end{abstract}

Consumer Behavior; Patient Satisfaction; Dental Health Services
Aline Macarevich 1

Luciane Maria Pilotto 2

Juliana Balbinot Hilgert 1

Roger Keller Celeste 1

doi: 10.1590/0102-311X00110716

\author{
Correspondence \\ A. Macarevich \\ Faculdade de Odontologia, Universidade Federal do Rio Grande \\ do Sul. \\ Rua Ramiro Barcelos 2492, 3o andar, Porto Alegre, RS \\ 90035-003, Brasil. \\ alinemacarevich@yahoo.com.br \\ 1 Faculdade de Odontologia, Universidade Federal do Rio \\ Grande do Sul, Porto Alegre, Brasil. \\ 2 Centro Universitário Univates, Lajeado, Brasil.
}




\section{Introduction}

Health services should be evaluated frequently to maintain or improve their quality levels. User satisfaction appears as one way of assessing the quality of health care and is an important outcome indicator ${ }^{1}$. It has also been used to evaluate the communication between professional and patient and to assist in choosing appropriate alternatives to organize the provision of health care 2 . User satisfaction is an important health behavior predictor and is a determinant in service use ${ }^{3}$. Dissatisfied patients may create a resistance in following professional orientation and not seek the same service for future references 4,5. To improve patient-centered care, one must assess user evaluation, because dentists cannot perceive patient dissatisfaction during the procedure 6 .

User satisfaction is considered an outcome related to the use of health services. It describes how the person perceived the service and the judgment about the care received, with the advantage of being a personal evaluation regarding the service and not only the normative or subjective perception of the patients' clinical conditions 7. As a multifactorial construct, the main dimensions usually evaluated are patient-professional interactions, physical environment and internal management processes 8 . Structural setting factors (accessibility, mode of payment, treatment length and waiting time), characteristics of patients (sociodemographic factors, expectations and health status) and of providers (personality and technical quality) also are related with user satisfaction ${ }^{3}$. Patient satisfaction includes users' views in the audit process and confirms the importance of users in the assessment of quality 9. It is particularly relevant in public services because it is an accountability resource. Thus, this assessment allows controlling, monitoring and strengthening the community participation in planning and exercising social control 10 .

The Brazilian health system is a network of complementary and competitive services, forming a public-private mix. The health system has three subsectors: the public subsector (Brazilian Unified National Health System - SUS), in which services are financed and provided by the State; the private subsector, for-profit and non-profit; and the private health plan or insurance subsector, with different forms of health plans. The public and private components of the system are distinct but interconnected, and people can use services in all three subsectors, depending on the ease of access or their ability to pay 11. The public oral health system has expanded mainly after 2004, with the implementation of the Brasil Sorridente (Smiling Brazil) policy 12.

The use of public or private dental services can be associated with different levels of patient satisfaction because of the differences of the services themselves, but also because of user characteristics 13,14. In the private service or private health plans, if users are not satisfied with the provided service, they have the option to seek other professionals, contrasting with the public service, where users are guided to specifically consult their health unit of reference, mostly by the Family Health Strategy, where there is a catchment area. In the public service, patients can access care without paying out-of-pocket, and cost may affect user satisfaction. Therefore, this article aimed to describe the levels of user satisfaction in different age groups and to study the association between user satisfaction and different types of dental services in a representative sample of Brazilians.

\section{Methods}

This study is based on the Brazilian Oral Health Survey (SB2010), a cross-sectional study with the primary objective of describing oral health status and dental service use in Brazil. The sample consisted of residents of 177 Brazilian cities in 2010, including all state capitals. The inclusion criteria were: individuals aged 5, 12, 15-19, 35-44 and 65-74 years old and being permanent resident of the selected census track. Individuals with cognitive disabilities and/or mental disabilities were excluded. In this study, only those who answered the questions about service satisfaction were evaluated, including adolescents, adults and older adults.

The sampling process followed a cluster design in two stages, in which primary sampling units were selected with probability proportional to the number of households. In the secondary sampling units, all eligible individuals, according to age group, were interviewed and examined by a trained dentist who used a structured questionnaire comprising closed questions. The potential "gratitude" 
bias was avoided, since the survey was conducted in a different setting (residence). Sampling weights were produced to correct for unequal probability selection 15 .

The outcome variable of this study, user satisfaction with type of dental service in the last dental visit, was collected using the following question: "What did you think about the dental treatment in your last visit?". The answer options ranged from "very good" to "very bad" on a five-level Likert-type scale. The main exposure variable, type of dental service, was collected by the question: "Where was your last dental visit? (a) public service; (b) private service (out-of-pocket); (c) private health plan or insurance; (d) other". The category "other" was excluded because of the small number of observations in this category.

The independent variables were: DMFT (decay, missing and filled teeth index, treated as a continuous variable); pain intensity in the past six months (six-point scale ranging from no pain to severe pain); reason for the last dental visit (prevention or check-up; pain; extraction; treatment); perceived need for treatment (no; yes); frequency of use of dental service (less than a year; from one to two years; three years or more); sex; equivalent income calculated as described in Celeste \& Bastos 16 (categorized into $0-1 / 2,1 / 2-1,1-2,2-3$ and more than 3 minimum wages); and educational level (categorized into 0-4, 5-8, 9-11 and more than 11 years of schooling).

All analyses were performed separately for each age group. Bivariate analyses were performed between user satisfaction and covariates to test their association using Pearson's chi-squared test and incorporating the sampling weights. A stepwise procedure was used for inclusion of the independent variables, entering first the lowest $p$-value and keeping in the final model only those variables with $\mathrm{p}<0.05$. Ordered logistic regression analyses were performed, fitting partial proportional regression according to Hosmer \& Lemeshow 17 for those covariates that violated the proportional odds assumption.

Four variables violated the proportional odds assumption (perceived need for treatment, pain intensity, educational level and frequency of use of dental service). To avoid extensive tables, we chose to present only the odds ratio of the main independent variable, where one set of odds ratio kept the proportional odds assumption. To assess the overall fit, we ran four binary logistic regressions with varying cut-off points on the dependent variable. The Hosmer \& Lemeshow goodness-of-fit test was acceptable for the final model. In addition, we tested the effect modification by macro-region for each age group. Data edition and analysis were performed using R (The R Foundation for Statistical Computing, Vienna, Austria; http://www.r-project.org) version 3.1.0. SB2010 was conducted in accordance with the standards of the Declaration of Helsinki and was approved by the National Research Ethics Committee, under the registration number 15,498, in January 7, 2010.

\section{Results}

SB2010 evaluated the dental health of 22,843 individuals in three age groups. However, in this study, we only analyzed 19,400 participants, because 2,813 individuals never visited the dentist and 630 individuals were considered losses. Most missing data was due to a closed household and not due to the respondents' refusal. Approximately $2 \%$ of no responses were due to personal rejection. The response rate among those eligible was $77.89 \%$ for adolescents, $61.02 \%$ for adults and $93.86 \%$ for older adults. Because of the missing data in the variables, the final multiple regression model included a sample of 4,534 adolescents, 8,822 adults and 6,044 older adults.

Concerning adolescents, $47.6 \%$ were male, $52.7 \%$ had equivalized household income up to 1 minimum wage (MW) and $82.2 \%$ had between 5 and 11 years of schooling. $48.1 \%$ of participants used public services, $40.2 \%$ used private services and only $11.7 \%$ used health plan. Few participants evaluated the services as bad or very bad (2.9\% and $1.4 \%$, respectively (Table 1$)$. In the crude model, adolescents who consulted the dentist in the public service were more dissatisfied than those who used a private service, and there was no statistical significance for those who used health plan $(\mathrm{OR}=$ 1.90; 95\%CI: 1.68-2.16 and OR = 0.94; 95\%CI: 0.78-1.14, respectively). After adjusting by covariates, the difference between public and private service remained, but lower $(\mathrm{OR}=1.34$; 95\%CI: 1.16-1.65) (Table 2). The variables DFMT, sex and education level were removed in the final model because they had no statistical significance. 
Table 1

Weighted percentage of user satisfaction according to type of service and age group in Brazil. Brazilian Oral Health Survey (SB2010).

\begin{tabular}{|c|c|c|c|c|c|c|}
\hline \multirow[t]{2}{*}{ Type of service * } & \multicolumn{6}{|c|}{ User satisfaction (weighted \%) } \\
\hline & Very good & Good & Regular & Bad & Very bad & Total \\
\hline \multicolumn{7}{|c|}{ Adolescent (15-19 years) } \\
\hline Total $[n=4,534]$ & 28.1 & 58.0 & 9.7 & 2.9 & 1.4 & 100.0 \\
\hline Public & 25.7 & 57.4 & 11.8 & 2.8 & 2.4 & 100.0 \\
\hline Private & 29.5 & 59.3 & 7.1 & 3.6 & 0.5 & 100.0 \\
\hline Health plan & 33.9 & 56.1 & 9.1 & 0.6 & 0.4 & 100.0 \\
\hline \multicolumn{7}{|l|}{ Adult (35-44 years) } \\
\hline Total $[\mathrm{n}=8,822]$ & 28.0 & 57.0 & 8.9 & 3.3 & 2.8 & 100.0 \\
\hline Public & 25.9 & 57.1 & 9.4 & 4.2 & 3.3 & 100.0 \\
\hline Private & 27.9 & 57.9 & 8.8 & 2.7 & 2.8 & 100.0 \\
\hline Health plan & 35.3 & 52.7 & 7.3 & 3.3 & 1.4 & 100.0 \\
\hline \multicolumn{7}{|c|}{ Older adult (65-74 years) } \\
\hline Total $[n=6,044]$ & 28.4 & 57.4 & 10.1 & 3.3 & 0.8 & 100.0 \\
\hline Public & 26.3 & 59.7 & 8.8 & 4.3 & 1.0 & 100.0 \\
\hline Private & 29.2 & 56.4 & 10.9 & 2.8 & 0.6 & 100.0 \\
\hline Health plan & 33.8 & 58.4 & 3.2 & 3.8 & 0.7 & 100.0 \\
\hline
\end{tabular}

* Chi-square $p<0.01$.

Table 2

Crude and adjusted odds ratio of user satisfaction with dental services according to type of service and age group in Brazil. Brazilian Oral Health Survey (SB2010).

\begin{tabular}{lcc}
\hline Type of service & $\begin{array}{c}\text { Crude model } \\
\text { OR (95\%Cl) }\end{array}$ & $\begin{array}{c}\text { Adjusted model * } \\
\text { OR (95\%Cl) }\end{array}$ \\
\hline $\begin{array}{l}\text { Adolescent (15-19 years) } \\
\quad \text { Private }\end{array}$ & 1.00 & 1.00 \\
$\quad$ Public & $1.90(1.68-2.16)$ & $1.34(1.16-1.65)$ \\
$\quad$ Health plan & $0.94(0.78-1.14)$ & $1.06(0.86-1.31)$ \\
Adult (35-44 years) & 1.00 & 1.00 \\
$\quad$ Private & $1.41(1.29-1.54)$ & $1.05(0.95-1.15)$ \\
$\quad$ Public & $0.97(0.86-1.10)$ & $1.15(1.01-130)$ \\
$\quad$ Health plan & & 1.00 \\
Older adult (65-74 years) & 1.00 & $0.96(0.84-1.09)$ \\
$\quad$ Private & $1.33(1.19-1.48)$ & $1.17(0.97-1.42)$ \\
$\quad$ Public & $0.95(0.80-1.13)$ & \\
Health plan & & \\
\hline
\end{tabular}

95\%Cl: 95\% confidence interval; OR: odds ratio.

* Adjusted by DMFT (decay, missing and filled teeth), sex, equivalent income, educational level, reason of dental visit, pain intensity, perceived need for treatment and frequency of use of dental services. 
Among adults, most were female (64\%), 45.6\% had income up to $1 \mathrm{MW}$ and $57.9 \%$ had from 5 to 11 years of schooling. Among older adults, $62.4 \%$ were female, $28 \%$ had equivalized household income up to $1 \mathrm{MW}$ and $61 \%$ had 4 or less years of schooling. The description of the main sociodemographic variables of the sample were described considering the sample weight. Adults and older adults used more private (45\% and 56.5\%, respectively) than public services (40.4\% adults and $33.9 \%$ ). Only $14.6 \%$ of adults and $9.6 \%$ of older adults used private health plan or insurance. Over $85 \%$ in both age groups evaluated the services as good or very good (Table 1). In the crude model, using the public service was associated with more dissatisfaction than using the private one (OR = 1.41; 95\%CI: 1.29-1.54), but there was no difference in using the health plan $(\mathrm{OR}=0.97 ; 95 \% \mathrm{CI}$ : 0.86-1.10) among adults. Similar results were found among older adults. However, in the adjusted model, the difference in user satisfaction between the private and public service lost the statistical significance for both age groups. However, the proportion of adults who used the services by health plans was associated with more dissatisfaction than using the private service $(\mathrm{OR}=1.15 ; 95 \% \mathrm{CI}$ : 1.01-1.30) (Table 2). DFMT was removed from the final model in both the adult and older adult groups. Sex was only removed from the final model in the adult group.

The effect modification by macro-region in each age group presented a small difference from the overall results. The difference between public and private service lost statistical significance among adolescents that lived in the South and Southeast regions $(\mathrm{OR}=1.41$; 95\%CI: 0.97-2.06 and OR = 0.73; 95\%CI: 0.51-1.04, respectively). In adults, the difference between private dentist and health plans only remained significant in the Northeast region (OR $=1.30$; 95\%CI: 1.08-1.67). Besides, a difference in the adjusted model was found between the use of services in the North and Southeast regions, where adults presented lower satisfaction $(\mathrm{OR}=1.55$; $95 \% \mathrm{CI}$ : $1.27-1.89)$ and higher satisfaction $(\mathrm{OR}=0.78$; 95\%CI: 0.62-0.99) with the public service compared to the private service, respectively. Among older adults, differences were found in the South region, where those who used the public service were more satisfied than those who used the private service (OR $=0.61$; 95\%CI: $0.43-0.86$ ), and in the North region, where those who used the public service or private health plan were more dissatisfied than those who used the private service $(\mathrm{OR}=1.33$; 95\%CI: $1.00-1.77$ and $\mathrm{OR}=1.80$; 95\%CI: 1.08 2.98 , respectively). Additional supplementary analyses regarding macro-regions can be obtained from the authors.

\section{Discussion}

The type of dental service was associated with user satisfaction only among adolescents. In this age group, those who visited a dentist in public service had more odds of being dissatisfied than those visited a private service. Furthermore, having consulted the dentist for over a year and reporting pain was significantly associated with lower user satisfaction.

In our study, all groups had high levels of satisfaction. Over 85\% participants evaluated the services as good or very good, regardless of age. This result contrasted with other authors, as older adults usually have more satisfaction than other age groups 18,19,20. The explanations for older people having more satisfaction include higher levels of tolerance and also the fact that professionals may be more respectful and careful in serving this population. It can also be a cohort effect, because older adults have lower expectations based on prior experiences or because the evaluation criteria are different due to specific values in the cohort 21,22. Compared with the last oral health survey (SB2003), the level of patient satisfaction among Brazilian older adults has decreased. In 2003, 4.5\% of older adults who used public service and $2.5 \%$ who used private/health plan evaluated it as "bad" or "very bad" in their last visit 14 . In 2010, 5.3\% of them evaluated the public service as "bad" or "very bad", 3.4\% did so for the private service and $4.5 \%$ did so for the health plan.

There was no statistically significant difference in the user satisfaction between private and public services in the adjusted model for older adults and adults. However, in adjusted models, difference was found between the private and health plan for adults. This could be explained by the lower costs for similar procedures in health plans compared to private services (out-of-pocket) and by the limited number of procedures covered by the dental plans. Although we could not find studies among adults, similar studies among older adults presented conflicting results. While one study showed that 
satisfaction levels were lower among users of the public service in 200214 , another showed lower satisfaction among users of private services in 2008 23. Such result disparities might be explained by differences in population context and time. For example, health plans for dental care are relatively new in the Brazilian context, and government regulations have been changing to adapt to user demands. The high level of satisfaction with no difference between the types of service can be considered a positive evaluation of public services, as the media tends to affect users' views, disqualifying the public service and overvaluing the private sector 24 .

In this study, it is not possible to infer which dimension of satisfaction is more affected by which type of services (public, private or health plan). We can rule out sociodemographic characteristics as an explanation, as our results were adjusted for them. Residual association can be related to the provider/service characteristics or its capacity to solve patients' complaints 13,25. Additionally, there is evidence that the waiting time is an important factor for lower satisfaction in public services 25 , which in our case can be considered a mediator and not a true confounder. The liberty to choose the provider has also been mentioned as a reason for satisfaction 13 , which does not occur in most public services that work under a specific catchment area.

Adolescents that use the public service are significantly less satisfied than those using private services, but the difference is small. Determinants of satisfaction may be different from adults to adolescents 26 . This may be because adolescents give more value to infrastructure, such as WiFi or the amenities available in private services. Other possibility is because the public service is oriented toward the needs of children and older adults or that it provides services in a way that does not fulfill adolescents' social values. If the adolescents do not feel accepted by the health team or if their expectations are not fully met, accessing the service might be more difficult. The patient-professional relationship is mentioned as a very relevant dimension of satisfaction for all age groups 27 , but it is stronger among adolescents. Authors also emphasize the lack of specific attention for adolescent care and that most professionals provide the same service to all age groups 28 . Besides the relationship with providers, factors such as quality of care and less postoperative complications were better evaluated in private services, and cost was the best factor of public services for adolescents 29 . The difficulty in accessing these services is the main reason for the low levels of adolescent satisfaction 24,30.

The type of treatment performed in public and private services may be another reason for the lower satisfaction of adolescents with the public service. In the private service, it is possible to perform specialized treatments not covered by basic health units, such as orthodontics or cosmetic procedures, which are highly valued by adolescents. However, for adults and older adults, the expansion of the type of service offered, such as the realization of roof canal or dental prostheses covered by SUS 12 , has the procedures carried out similarly by public and private services.

The previous experience and expectancy can affect user satisfaction 31. Public dental care has expanded 32, especially with the improvement in physical infrastructure, the increase in number of primary oral health care teams and the creation of Dental Specialty Centers (CEO, acronym in Portuguese) ${ }^{12}$. It is possible that adults and older adults perceived such changes as improvements in the quality of public oral service because of the Smiling Brazil policy, reducing differences between public and private oral care and improving the public service satisfaction.

It is known that there are socioeconomic and cultural inequalities between Brazilian regions, as well as differences in provision, access and use of health services 33 . When effect modification by macro-regions was tested for each age group, the results showed small difference. In the South and Southeast regions, adults and older adults showed greater satisfaction with the use of the public service compared with private services, while adolescents did not show any statistical difference. In recent years, these regions have expanded their use of SUS, despite having the highest private health coverage 33 . Users from those regions probably choose the public service because of its quality, greater access and service organization. Our results, thus, corroborate the findings of other studies 34 . The North and Northeast regions showed the lowest satisfaction levels with public service and with private health plans compared with private services in all age group. Other studies also showed that less favored regions have more disease burden 35 , worse evaluations of health condition 33,36 and lower use of dental services, which would affect the results. However, for oral health conditions (DMFT) were controlled and still differences remained. The influence of regional differences on user satisfaction with different types of service needs further investigation. 
The fact that this study is cross-sectional is a limitation, thus we cannot be sure about temporal order. Further, there may be the "gratitude bias," because users may feel obliged to give a good evaluation to maintain the treatment. Gratitude bias is the omission of questions and negative reviews of users, and is found especially in the evaluation of public services 10 . However, the fact that the interviewer was not part of the service team and that it was a household survey reduce the possibility of such bias. Another limitation is that a global question mixes the multiple dimensions of satisfaction, so we cannot confirm which dimension (physical structure, patient-professional relationship or health problem solution) was most affected by each type of service. However, satisfaction is also considered an outcome in health and, as well as the perception of oral health, can be evaluated by global questions in epidemiological studies of national base 37 . Besides, there is not a consensus about a gold standard instrument for user satisfaction measurement in health care 8 . Considering that the item on satisfaction questions is about the last dental visit, and that its duration varies from individual to individual, memory bias is possible. Validation studies on this aspect are also needed.

The strengths of this study include a large and representative sample of the Brazilian population; the possibility to control by potential associated factors and the evaluation of user satisfaction in different age groups. As satisfaction depends on user characteristics, service and provider, this national baseline study can be generalized for the Brazilian population and other developing countries with similar characteristics.

Brazilians are very satisfied with dental services, but, among adolescents, dental visits in public services were associated with lower satisfaction. Public services improved the quality of care, but may focus on issues related to children, adults and older adults and not on the adolescent audience, which has specific demands. Our findings indicate the need to maintain the oral health public policies and also to include the adolescents' perspective. Multidimensional and population-based instruments should be developed to assess user satisfaction, understand the differences between the types of services and to improve each dimension of satisfaction and care.

\section{Contributors}

A. Macarevich participated in all aspects of the study, including the drafting of the manuscript and data analysis and interpretation. L. M. Pilotto and J. B. Hilgert contributed to data analysis and interpretation and to the critical review of the manuscript. R. K. Celeste participated in study design and coordination, data analysis and interpretation and critical review of the manuscript.

\section{Acknowledgments}

L. M. Pilotto received financial support from Brazilian Graduate Studies Coordinating Board (Capes) and authors R. K. Celeste and J. B. Hilgert are CNPq (Brazilian National Research Council) productivity researchers. The other authors have no financial relationships important to this article.

\section{Conflict of interest}

The authors declare no conflict of interest. 


\section{References}

1. Donabedian A. The quality of medical care. Science 1978; 200:856-64.

2. Fitzpatrick R. Surveys of patient satisfaction: I - important general considerations. BMJ 1991; 302:887-9.

3. Weiss GL. Patient satisfaction with primary medical care : evaluation of sociodemographic and predispositional factors. Med Care 1988; 26:383-92.

4. Williams B. Patient satisfaction: a valid concept? Soc Sci Med 1994; 38:509-16.

5. Albrecht G, Hoogstraten J. Satisfaction as a determinant of compliance. Community Dent Oral Epidemiol 1998; 26:139-46.

6. Riley 3rd JL, Gordan VV, Hudak-Boss SE, Fellows JL, Rindal DB, Gilbert GH, et al. Concordance between patient satisfaction and the dentist's view: findings from the National Dental Practice-Based Research Network. J Am Dent Assoc 2014; 145:355-62.

7. Andersen RM, Davidson PL. Ethnicity, aging, and oral health outcomes: a conceptual framework. Adv Dent Res 1997; 11:203-9.

8. Almeida RS, Bourliataux-Lajoinie S, Martins M. Satisfaction measurement instruments for healthcare services users: a systematic review. Cad Saude Pública 2015; 31:11-25.

9. Sitzia J, Wood N. Patient satisfaction: a review of issues and concepts. Soc Sci Med 1997; 45:1829-43.

10. Esperidião M, Trad LA. User satisfaction assessment. Ciênc Saúde Coletiva 2005; 10 Suppl:303-12.

11. Paim J, Travassos C, Almeida C, Bahia L, Macinko J. The Brazilian health system: history, advances, and challenges. Lancet 2011; 377:1778-97.

12. Pucca Jr. GA, Gabriel M, Araujo ME, Almeida FC. Ten years of a national oral health policy in Brazil: innovation, boldness, and numerous challenges. J Dent Res 2015; 94:1333-7.

13. Gouveia GC, Souza WV, Luna CF, SouzaJúnior PR, Szwarcwald CL. Health care users' satisfaction in Brazil, 2003. Cad Saúde Pública 2005; 21 Suppl 1:S109-18.

14. Martins AM, Jardim LA, Souza JG, Rodrigues CA, Ferreira CR, Pordeus IA. A avaliação negativa dos serviços odontológicos entre idosos brasileiros está associada ao tipo de serviço utilizado? Rev Bras Epidemiol 2014; 17:71-90.

15. Silva NN, Roncalli AG. Sampling plan, weighting process and design effects of the Brasilian Oral Health Survey. Rev Saúde Pública 2013; 47 Suppl 3:3-11.

16. Celeste RK, Bastos JL. Mid-point for openended income category and the effect of equivalence scales on the income-health relationship. Rev Saúde Pública 2013; 47 Suppl 3:168-71.

17. Hosmer DW, Lemeshow S. Applied logistic regression. 2nd Ed. New York: Wiley; 2000.
18. Ayala-Luis J, Johansson V, Sampogna F, Axtelius B, Söderfeldt B. A multivariable analysis of patient dental satisfaction and oral healthrelated quality-of-life. A cross-sectional study based on DVSS and OHIP-14. Acta Odontol Scand 2014; 72:187-93.

19. Hall JA, Dornan MC. Patient sociodemographic characteristics as predictors of satisfaction with medical care: a meta-analysis. Soc Sci Med 1990; 30:811-8.

20. Jackson JL, Chamberlin J, Kroenke K. Predictors of patient satisfaction. Soc Sci Med 2001; 52:609-20.

21. Aspinal F, Addington-Hall J, Hughes R, Higginson IJ. Using satisfaction to measure the quality of palliative care: a review of the literature. J Adv Nurs 2003; 42:324-39.

22. Crow R, Gage H, Hampson S, Hart J, Kimber A, Storey L, et al. The measurement of satisfaction with health care: implications for practice from a systematic review of the literature. Health Technol Assess 2002; 6:1-244.

23. Rodrigues CA, Silva PL, Caldeira AP, Pordeus IA, Ferreira RC, Martins AM. Factors associated with satisfaction with dental services among the elderly. Rev Saúde Pública 2012; 46:1039-50.

24. Magalhães BG, Oliveira RS, Góes PSA, Figueiredo N. Avaliação da qualidade dos serviços prestados pelos Centros de Especialidades Odontológicas: visão dos usuários. Cad Saúde Colet (Rio J.) 2015; 23:76-85.

25. Passero LG, Giordani JMA, Hugo FN, Torman VBL, Camey AS, Hilgert JB. Contextual and individual factors associated with dissatisfaction with the Brazilian Unified National Health System, 2011-2012. Cad Saúde Pública 2016; 32:e0065015.

26. Litt IF. Satisfaction with health care: the adolescent's perspective. J Adolesc Health 1998; 23:59-60.

27. Armefield JM, Enkling N, Wolf CA, Ramseier CA. Dental fear and satisfaction with dental services in Switzerland. J Public Health Dent 2014; 74:57-63.

28. Okullo I, Astrom AN, Haugejorden O. Influence of perceived provider performance on satisfaction with oral health care among adolescents. Community Dent Oral Epidemiol 2004; 32:447-55.

29. Al-Hussyeen AJA. Factors affecting utilization of dental health services and satisfaction among adolescent females in Riyadh City. Saudi Dent J 2010; 22:19-25.

30. Lima ACS, Cabral ED, Vasconcelos MMVB. Satisfação dos usuários assistidos nos Centros de Especialidades Odontológicas do Município do Recife, Pernambuco, Brasil. Cad Saúde Pública 2010; 26:991-1002. 
31. Doyle C, Lennox L, Bell D. A systematic review of evidence on the links between patient experience and clinical safety and effectiveness. BMJ Open 2013; 3:e001570.

32. Frazão P, Narvai PC. Saúde bucal no Sistema Único de Saúde: 20 anos de lutas por uma política pública. Saúde Debate 2009; 33:64-71.

33. Viacava F, Bellido JG. Health, access to services and sources of payment, according to household surveys. Ciênc Saúde Coletiva 2016; 21:351-70.

34. Gouveia GC, Souza WV, Luna CF, Souza-Júnior PRB, Szwarcwald CL. Satisfação dos usuários do sistema de saúde brasileiro: fatores associados e diferenças regionais. Rev Bras Epidemiol 2009; 12:281-96.
35. Costa SM, Abreu MHNG, Vasconcelos M, Lima RCGS, Verdi M, Ferreira EF. Desigualdades na distribuição da cárie dentária no Brasil: uma abordagem bioética. Ciênc Saúde Coletiva 2013; 18:461-70.

36. Ferreira CO, Antunes JLF, Andrade FB. Factors associated with the use of dental services by elderly Brazilians. Rev Saúde Pública 2013; 47 Suppl 3:90-7.

37. Atchinson KA, Gift HC. Perceived oral health in a diverse sample. Adv Dent Res 1997; 11:272-80. 


\section{Resumo}

$\mathrm{O}$ artigo teve como objetivos descrever os níveis de satisfação de usuários de diferentes grupos etários e analisar a associação entre satisfação de usuários e diferentes tipos de serviços odontológicos em uma amostra representativa de brasileiros. $\mathrm{O}$ estudo é baseado na Pesquisa Nacional de Saúde Bucal, que avaliou a saúde oral dos adolescentes, adultos e idosos em 177 cidades brasileiras. A variável de desfecho era a satisfação do usuário em relação à última consulta odontológica, avaliada através da uma escala de tipo Likert, com cinco níveis. A principal variável de exposição era o tipo de serviço de saúde oral (público, privado, plano ou seguro odontológico). As variáveis independentes eram o índice CPOD (dentes cariados, perdidos e obturados); intensidade de dor nos últimos seis meses; motivo pela última consulta odontológica; percepção de necessidade de tratamento; frequência de uso de serviços de saúde oral; sexo; renda equivalente e escolaridade. Foram realizadas análises separadas de regressão logística ordinal para cada faixa etária. Poucos participantes avaliaram os serviços como ruins ou muito ruins (4,3\% dos adolescentes, 6,1\% dos adultos e 4,1\% dos idosos). Entre todos os grupos, no modelo não ajustado, o uso de serviços públicos esteve associado à satisfação mais baixa em comparação com os serviços privados e planos de saúde. Entretanto, após ajustar pelas covariáveis, esta associação se manteve apenas nos adolescentes, que mostraram menor satisfação com os serviços públicos em comparação com os serviços privados e planos de saúde. Em geral, os brasileiros estão satisfeitos com os serviços de saúde oral; no entanto, entre os adolescentes o uso de serviços públicos esteve associado à menor satisfação. É possível que os serviços públicos estejam orientados para as questões das crianças, dos adultos e dos idosos, mas não do público de adolescentes, que apresentam demandas específicas.

Comportamento do Consumidor; Satisfação do Paciente; Serviços de Saúde Bucal

\section{Resumen}

El objetivo de este artículo fue describir los niveles de satisfacción de los usuarios en diferentes grupos de edad, además de estudiar la asociación entre la satisfacción del usuario y los diferentes servicios dentales, en una muestra representativa de ciudadanos brasileños. Este estudio está basado en la Encuesta de Salud Bucal Brasileña, que evaluó la salud dental de adolescentes, adultos y adultos de edad avanzada en 177 ciudades brasileñas. La variable de resultado fue la satisfacción del usuario, en relación con la última visita dental, evaluada en una escala tipo Likert de cinco niveles. La variable principal de exposición fue el tipo de servicio dental (servicio público, servicio privado, plan de salud o seguro). Las variables independientes fueron DCPO (dientes cariados, perdidos y obturados); intensidad del dolor en los últimos seis meses; razón de la última visita dental; necesidad percibida de tratamiento; frecuencia del uso de los servicios dentales; sexo; ingresos equivalentes; $y$ nivel educacional. Se realizó un análisis por regresión logística ordinario separadamente para cada grupo de edad. Algunos participantes evaluaron los servicios como deficitarios o muy deficitarios (4,3\% de los adolescentes, 6,1\% de los adultos y un 4,1\% de los adultos de edad más avanzada). En el modelo sin estratificar, el uso de los servicios públicos estuvo asociado con una satisfacción más baja que el uso de servicios privados y planes de salud entre todos los grupos. No obstante, tras ser ajustado por las covariables, la asociación se mantuvo sólo en los adolescentes, que mostraron una satisfacción más baja con el servicio público, en comparación con los servicios privados y planes de salud. En general, los brasileños están satisfechos con los servicios dentales, sin embargo, entre los adolescentes, el uso de los servicios públicos estuvo asociado con una baja satisfacción. Los servicios públicos tal vez se centran en asuntos relacionados con niños, adultos y adultos de edad avanzada, y no con el público adolescente que demanda servicios específicos.

Comportamiento del Consumidor; Satisfacción del Paciente; Servicios de Salud Dental
Submitted on $26 /$ Jun/2016

Final version resubmitted on 26/Apr/2017

Approved on 27/Jun/2017 